\title{
崖酸ガスレーザー照射による家鬼舌組織の変化に関する基礎的研究
}

\author{
福田廣志

\section{Experimental study on the effect of irradiation with carbon dioxide laser on tongue of rabbit}

\author{
Hiroshi FukudA
}

\begin{abstract}
A 2mm spot size focused beam from a continuous wave surgical carbon dioxide laser with diameter, integrated with an operating microscope was used to evaporate the normal dorsal surfaces of rabbit tongues under different conditions. The immediate effects of irradiation with carbon dioxide laser on the dorsal surface of the tongue were studied macroscopically and microscopically, and wound healing was examined microscopically, 1, 3, 5, 7, 14 and 21 days after he laser irradiation. The results were as follows.

1) The immediate change induced by a focused beam carbon dioxide laser was characterized by white coloration on the targetarea up to a laser emission of 1 Joul and by tissue defect formation when emission exceeded 2 Joul.

2) Tissue defect was characterized by a cone shape, and the floor of the defective was portion was slightly elevated at its center in some cases. The margin of the defective portion was slightly elevated over surrounding normal tissue.

3) The depth of tissue defect varied with output power and irradiation time. In the same output power, the depth of tissue defect was directly proportional to irradiation time.

4) Microscopic findings immediately after the laser irradiation varied with irradiation conditions. At 5 watts $0.1 \cdot 0.2 \cdot 0.5$ second and 10 watts 0.1 second laser irradiations, tissue damage was only seen at the prickle-cell layer of the mucosal epithelium and the basal layer was not damaged. At 5 watts $\cdot 1.0$ second, 10 watts 0.2 second, 15 watts $0.1 \cdot 0.2$ second and 20 watts 0.1 second laser irradiations, tissue damage was seen beyond the basement membrane and in the submucosal layer, but the muscle layer was not damaged. At 10 watts $0.5 \cdot 1.0$ second, 15 watts $\cdot 0.5 \cdot 1.0$ second and 20 watts $\cdot 0.2 \cdot 0.5 \cdot 1.0$ second laser irradiations, the muscle layer was damaged.

5) Wound healing differed according to the depth of tissue damage immediately after the laser irradiation mentioned above. Wound healing was fast and finished within 7 days after the laser irradiation in the group that tissue damage was limited only to the prickle-cell layer of the mucosal epithelium. In the group that tissue damage was seen beyond the basement membrane and in the submucosal layer, and did not extend to the muscle layer, wound healing finished within 14 days after laser irradiation, but in the group that tissue damage extended to the muscle layer, 21 days were necessary to complete wound healing.
\end{abstract}

東京医科歯科大学歯学部第 1 口腔外科学教室 （主任：塩田重利教授）

現：筑波大学臨床医学系口腔科

(主任：根本一男教授)

The First Department of Oral Surgery, Faculty of

Dentistry, Tokyo Medical and Dental University
(Chief: Prof. Shigetoshi Shioda)

Present address: Department of Stomatology, Institute of Clinical Medicine, University of Tsukuba (Chief: Prof. Kazuo Nemoto)

受付日：昭和60年 1 月25日 
From these results, it is speculated that the carbon dioxide laser will be effective to remove superficial lesions of the oral mucosa and of benefit to oral and maxillofacial surgery.

Key words: carbon dioxide laser, oral mucosa, experimental study

緒

\section{言}

手術の基本操作は，切離，止血，縫合の 3 要素からな り1)，なかでも止血操作烧間を要することが多く，明 視下で安全確実な手術を行うためにも，出血をでさる限 り少なくすることが望ましい， 口腔領域の手術に扔いて る，基本操作は同じであるが，口腔領域の解剖学的特珄 すなわち血管が豊富であり術野が狭いこと等より，出血 しやすく，止血が困難なことが多い．

一方, 口腔粘膜に発症する表在性病変も多く, 白板症, 扁平苔癄等では外科的切除術が適応になることもある。 しかし，現在使用されている鋼为メスや電気メスによる 切除では，一定の深さで広箷囲の病変を切除することは 技術的に困難であり，出血を伴う等の欠点を有して括 り，無血的手術法の確立が望まれる。

1960年 Maiman²)がルビーレーザーの発振に成功して 以来, 種々の波長のレーザーが開発され，工学, 医学等の 各種領域で応用されているが，とりわけ，1964年 Patel ${ }^{3)}$ により開発された炭酸ガスレーザーは $10.6 \mu \mathrm{m}$ で遠赤 外線領域の波長を有し，生体組織に対する吸収係数が一 様炕大きく4，したがって炭酸ガスレーザーの組織表面 からの反射率は低く，注一定の効率で生体組織は切 離, 蒸散され，かつ毛細血管など細かい血管は凝固・閉 塞されることから，無血的な手術が可能であり， 口腔粘 膜病変の切除への応用も有用之考党られる.

しかし、レーザー照射の特改は，直接組織に接触する ことなく，組織の切断，蒸散が行われることであり，従 来の接触型の鋼刃メス，電気メスに比べ，深さの調節が 困難であり，術者の経験，習熟が必要であるといら久点 を有している。ま口腔粘膜は皮膚と比較して一般に薄 く，その直下に骨，神経，血管，唾夜腺管等が存在する 場合が多く，また口腔内には歯が植立しているなどの特 殊な形態を有しており，これらの組織を損傷しないため にも，正確な深さの調節が必要となる。このような形態 学的拉よび組織学的な特徵を有する口腔粘膜に炭酸ガス レーザーを照射する場合，照射によって生じる口腔粘膜 の組織学的変化を詳細に検索し，かつ照射による粘膜損 侮の治㾍過程を䅅時的に明らかにすることは，本レーザ 一を臨床に応用する上できわめて重要な問題であると考 えられる。

そこで著者は，炭酸ガスレーザー照射による口腔粘膜 の即時変化である組繳欠損の深さ，および照射創の治療



写真 1 炭酸ガスレーザー (Coherent 社 製 System 400 Surgical Laser(B) 抌よび手政用顕锁鏡(Zeiss OMPI 1 Operating Microscope()

過程を知る目的で家鬼を用いた実験を行い，肉眼的なら びに組織学的に観察し，若干の知見を得たので報告す る.

\section{実験動物ならびに使用機器}

\section{1. 実験動物}

実験に使用した動物は，体重 $2.5 \mathrm{~kg}$ 前後の日本白色 家鬼で，東京医科齿科大学医学部附属動物実験施設内の 恒温 $\left(22 \pm 1^{\circ} \mathrm{C}\right)$, 恒湿 $(55 \pm 5 \%)$ にて Oriental RC5 固型飼料と水で 1 週間以上飼有し, 異常のないことを 確認した後, 実験に供した。

\section{2. 使用機器}

レーザー照射には，波長 $10.6 \mu \mathrm{m}$ の㞸酸ガスレーザ - (Coherent 社製 System 400 Surgical Laser(B) を使 用した，本機は，焦点距離 $400 \mathrm{~mm}$, 焦点位直径 $2 \mathrm{~mm}$ で，出力は最大 25 watts まで連続的に調節でき，照射 部位の決定には炭酸ガスレーザーと同軸のーリウム・ネ オンガイド光を使用している．照射時間は，0.1秒，0.2 秒，0.5秒，1.0秒，および連続照射が可能である（写真 1 ). 




写真 2 出力測定装置 (Coherent 社製 model 201 Power Meter(B)



写真 3 家象舌背の铄引固定

炭酸ガスレーザーの照射部位での出力の測定には， power meter (Coherent 社製, Model 201 Power Meter®) を使用した（写真 2)。

\section{実 験 方 法}

\section{1. レーザー照射}

Nembutal® $(0.5 \mathrm{~m} l / \mathrm{kg})$ 静脈麻酔下飞，家鬼を 腹位 に固定後，舌背部を口腔外に牽引回定し、レーザー装賾 に取り付けられた手術用影呲鏡 (Zeiss OMP I 1 Operating Microscope( ())による拡大視野下に，炭酸ガスレ ーザー光が家鬼舌背面に直角你射されるように，レー ザー装置の位固を決め, 炭酸ガスレーザーの出力 5 watts, 10 watts, 15 watts, 20 watts とし，それそれれ照射時間を 0.1 秒，0.2秒，0.5秒，1.0 秒で焦点位にて照射した(写 真 3 ).

実験は 2 群に分け，1群の舌背で左側には 5 watts, 右側には 20 watts, 他の 1 群の舌背で左側には 10 watts, 右側には 15 watts の照射出力で, 舌集から舌根に向か 以照射時間がそれそれ 1.0 秒，0.5秒，0.2秒，0.1 秒と

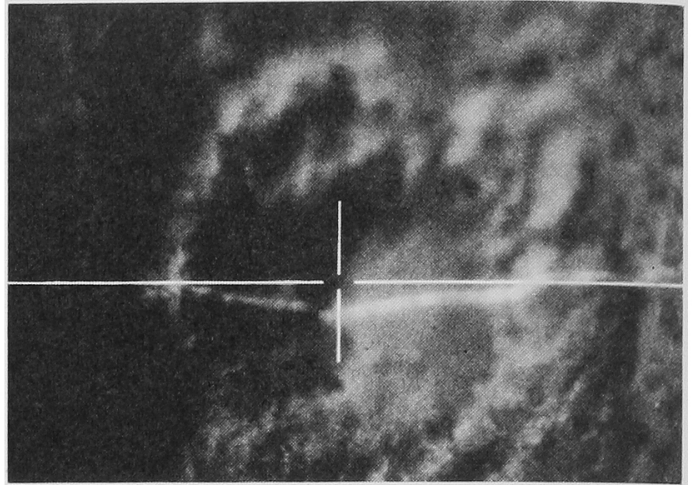

写真 4 ミクロン深さ高さ測定機によるレーザー照 射直後の組織欠損部舌背模型の深さ測定.

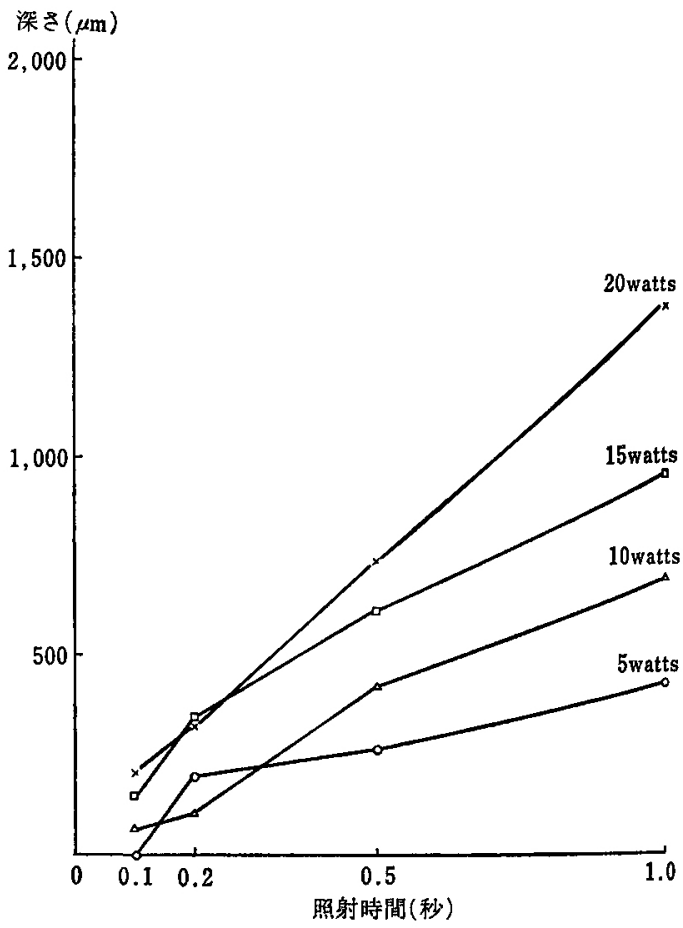

図 1 レーザー照射直後の欠損部の深さ

なるよらに炤射した，照射直後の深さ湘定，組織学的観 察に各群 5 羽, 計10羽，照射後の組維学的観察（1日， 3 日，5 日，7日，14日，21日後）飞各群18羽，計 36 羽 を実験に供した。

実験に際して，術者は防護用メガネを着用し，レーザ 一実験室を独立させ，事故防止を計った。

2.レーザー照射直後の欠損部の深さ測定法

瑱部組織の久損部の深さ测定は天笠 $(1973)^{5)}$ の方法に 準じた，レーザー照射值後の舌背を，シリコーンラバー 


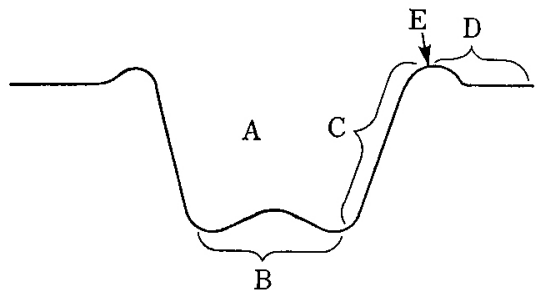


A : 組織欠賣
B：組織欠提の底面
C : 租絨欠損の辺縁部
D：組緎欠損の周辺部
$\mathrm{E}$ ：境界部

印象材 (Bayer 社留，Xantpren() を用い印象採得し， 硬石膏 (而至社製，ニュープラストン囚) で舌背模型を 作製した，ついで，ミクロン深さ高さ剆定機（日商精密 光学工業社製）を用い，舌背模型の被檢部位表面が測定 台に平行になるよらに固定し，同一墭所を 5 回測定し た (写真 4 ).

3.レーザー照射後の創の肉眼的, 組織学的観察

照射直後，1日，3日，5日，7日，14日，21日後の 各時期に経時的に，肉眼的に観察した後，屠殺し，組織 を採取し，10\%リン酸緩衝ホルマリン液に固定後，通法 に従いパラフィンに包埋し，厚さ5 $\mu \mathrm{m}$ の切片を作製し， Hematoxylin-Eosin 染色を行い観察した.

\section{実 験 成 績}

\section{I.レーザー照射直後の照射部位の変化}

1. 顿部組織の欠損部の深さ（図 1)

測定部位は，レーザー照射の影響のない舌背表面から レーザー照射後の組織欠損の最深部までを，おのおのの 舌背模型につき 5 回测定し、その平均值をそれぞれの組 織欠損の媣さとし，照射出力，照射時間が同一条件の舌 背模型，5個についての平均值扎よび標準偏差值を求め た、実験結果は下記のとおりである。

5 watts 群: 0.1 秒 $; 0 \mu \mathrm{m}, 0.2$ 秒 $; 195 \pm 179 \mu \mathrm{m}, 0.5$ 秒; $265 \pm 42 \mu \mathrm{m}, 1.0$ 秒 $; 423 \pm 197 \mu \mathrm{m}$

10 watts 群 : 0.1 秒; $63 \pm 89 \mu \mathrm{m}, 0.2$ 秒 ; $101 \pm 70 \mu \mathrm{m}$, 0.5 秒； $419 \pm 161 \mu \mathrm{m} ， 1.0$ 秒； $687 \pm 357 \mu \mathrm{m}$

15 watts 群: 0.1 秒; $139 \pm 119 \mu \mathrm{m}, 0.2$ 秒; $342 \pm 107$ $\mu \mathrm{m}, 0.5$ 秒 ; $607 \pm 124 \mu \mathrm{m}, 1.0$ 秒 ; $949 \pm 311 \mu \mathrm{m}$

20 watts 群 : 0.1 秒；205土 $140 \mu \mathrm{m}, 0.2$ 秒；322士157 $\mu \mathrm{m} ， 0.5$ 秒 $; 731 \pm 230 \mu \mathrm{m} ， 1.0$ 秒 $; 1374 \pm 244 \mu \mathrm{m}$

2. 肉眼所見：レーザー照射後の照射部位の変化は, 本論文では，各部位の名称を以下のように定義した（図 2, 写真 5, 6).

組織欠損：レーザー照射後の照射部位に生じた実質欠

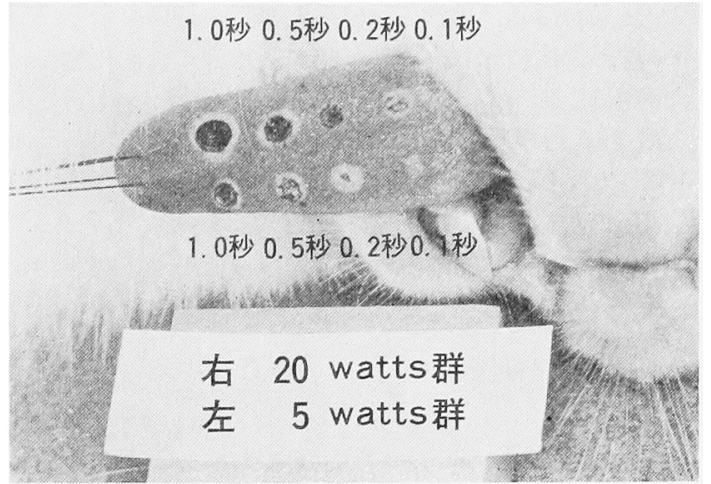

写真 5 レーザー照射直後の炤射部位の变化（5 watts 群, 20 watts 群).

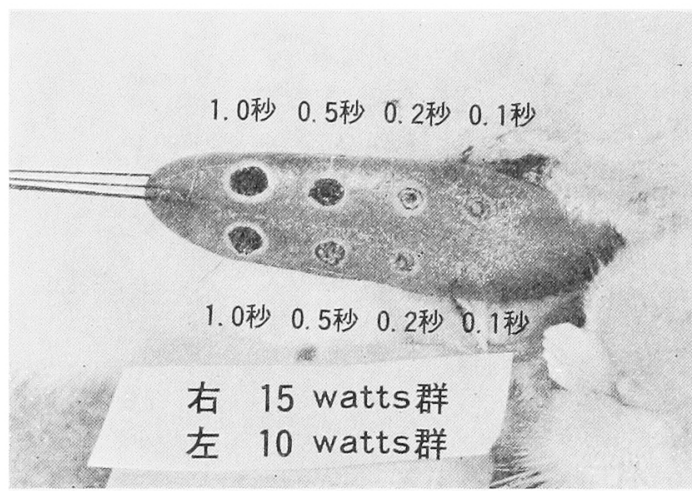

写真 6 レーザー炤射直後の炤射部位の変化(10 watts 群, 15 watts 群).

損で軟組蟣の陷凹した部分

組織欠損の底面 : 組織欠損の最樑部分

組織欠損の辺緣部：組織欠損の側壁部分

組織欠損の周辺部：組織欠損の周再の舌背表面で，軟 組織の奏質欠損のみられない部分

境界部：組織欠損の辺縁部と組織欠損の周辺部との境 界

1) 5 watts 群

0.1 秒レーザー照射（以下，照射と略す）では，照射 部位に一致して舌背表面は円形に脱色され，白色となっ ているが，組織欠損，炭化物の付着，出血は認められな w

0.2 秒照射では，照射部位に一致して円形に脱色され， 白色の変化を示している. 円形，白色に変化した部の中 央では，一部に粘膜上皮の組織欠損がみられ，表面には 炭化物の付着が認められる。

0.5 秒照射では，照射部位に一致して舌背衣面は円形， 白色に変化し，円形，白色に変化した部の中央では組織 が欠損し，組織欠損の底面の中央は舌背表面に向けて凸 
の小隆起を認め，組織欠損は倒円錐形の形態を示してい る. 境界部は隆起し, 組織欠損の辺縁部には炭化物の付 着が認められる。

1.0 秒照射では，照射部位に一致した組織欠損が認め られる，境界部は隆起し，組織欠損の周辺部が円形，白 色変化している．組織欠損の底面の中央は舌背表面に 向けて凸の小隆起を認め, 組織欠損は倒円錐形の形態を 示している. 組織欠損の辺縁部では炭化物の付着が認め られる。

2) 10 watts 群

0.1 秒照射では，照射部位に一致して円形に脱色され， 白色に変化している．円形，白色に変化した部の中央で は一部に粘膜上皮の組織欠損があり，組織欠損の表面に は炭化物の付着が認められるものもある.

0.2 秒照射では，照射部位に一致して円形に脱色され， 白色に变化し，円形，白色に変化した部の中央では組織 が欠損し，組織欠損の底面の中央が舌背表面に向けて凸 の小隆起を示し，組織欠損は倒円錐形の形態を示してい る. 境界部は隆起し, 組織欠損の辺縁部には炭化物の付 着が認められる。

0.5 秒照射では，照射部位に一致した 組織欠損が認め られる。境界部は隆起し, 組織欠損の周辺部は円形, 白 色に変化している。組織欠損の底面の中央には舌背表面 に向けて凸の小隆起を認め, 組織欠損は倒円錐形の形態 を示し，組織欠損の辺縁部では炭化物の付着を認める.

1.0 秒照射では， 0.5 秒照射と同様に照射部位に一致し た組織欠損が認められる。境界部は隆起し，組織欠損の 周辺部は円形, 白色に变化している．組織欠損の底面の 中央には舌背表面に向けて凸の小隆起を認め, 組織欠損 は倒円錐形の形態を示し, 組織欠損の辺縁部には, 炭化 物の付着が認められる。

3) 15 watts 群

0.1 秒照射では，照射部位に一致して円形に脱色され， 白色に变化し, 円形，白色に変化した部の中央では組織 欠損を認め，組織欠損の底面の中央には舌背表面に向け て凸の小隆起を認め, 組織欠損は倒円錐形の形態を示し ている，境界部は隆起し，組織欠損の辺縁部には炭化物 の付着を認めるが，炭化物の量は少ない

0.2 秒照射では，照射部位に一致して組織欠損が認め られる，境界部は隆起し，組織欠損の周辺部が円形，白 色に変化している．組織欠損の底面の中央には舌背表面 に问けて凸の小隆起を認め, 組織欠損は倒円錐形の形態 を示し, 組織欠損の辺縁部には炭化物の付着が認められ る.

0.5 秒照射では，照射部位に一致した 組織欠損が認め られる，境界部は隆起し，組織欠損の周辺部が円形，白 色に変化している，組織火損の底面の中央には舌背裴面 に向けて凸の小隆起を認め, 組織欠損は倒円雓形の形態 を示し, 組織欠損の辺縁部には炭化物の付着が認められ
る.

1.0秒照射では，照射部位に一致した組織欠損が認め られる。境界部は隆起し, 組織欠損の周辺部が円形, 白 色に変化している．組織欠損の底面は平坦で倒円錐形の 形態を示し, 組織欠損の辺縁部には炭化物の付着が認め られる。

4) 20 watts 群

0.1 秒照射では，照射部位に一致して円形に脱色，白 色に変化し, 円形, 白色に変化した部の中央には組織欠 損を認め, 組織欠損の底面の中央には舌背表面に向けて 凸の小隆起を認め, 組織欠損は倒円錐形の形態を示して いる，境界部が隆起し，組織欠損の辺縁部には炭化物の 付着が認められる。

0.2 秒照射では，照射部位に一致した 組織欠損が認め られる。境界部は隆起し, 組織欠損の周辺部が円形, 白 色に変化している。組織欠損の底面の中央には舌背表面 に向けて凸の小隆起を認め, 組織欠損は倒円錐形の形態 を示し, 組織欠損の辺縁部には炭化物の付着が認められ る.

0.5 秒照射では，照射部位に一致した 組織欠損が認め られる。境界部は隆起し, 組織欠損の周辺部が円形, 白 色に变化している。組織欠損の底面の中央には舌背表面 に向けて凸の小隆起を認め, 組織欠損は倒円錐形の形態 を示し，組織欠損の辺縁部には炭化物の付着が認められ る. 10 watts 0.5 秒照射に比べ，組織欠損の深さは増し ている。

1.0秒照射では，照射部位に一致した 組織欠損が認め られる。境界部は隆起し, 組織欠損の周辺部が円形, 白 色に変化している。組織欠損の底面は平坦な倒円錐形の 形態を示し, 組織欠損の辺縁部には炭化物の付着が認め られる。

3. 組織学的所見

炭酸ガスレーザー照射直後の組織学的変化は, 変化の 深さに応じて次の 3 群に分けて微察した。

I 群 : 組織学的変化が粘膜上皮の有棘層にのみ限局 し，基底層およびその深部に変化が認められなかったも の (5 watts ・ 0.1秒・0.2秒・0.5秒, 10 watts ・ 0.1 秒照 射群)

II 群：組織学的変化が基底層, 粘膜固有層に及ぶが, 等㬝には変化が認められなかったもの（5 watts・1.0秒， 10 watts 0.2 秒, 15 watts 0.1 秒 $\cdot 0.2$ 秒, 20 watts 0.1 秒照射群)

III群: 組䄉学的変化が䇗層に及儿でいたもの(10 watts 0.5 秒・ 1.0 秒, 15 watts 0.5 秒・ 1.0 秒, 20 watts 0.2 秒・ 0.5 秒・ 1.0 秒照射群)

I 群：粘膜上皮の組織欠損は組織欠損の辺縁部で深 く，中央部でやや浅く，一部に炭化物の付着を認めるも のもみられる。残存した粘膜上皮は上皮細胞の核が消失 し，好酸性色素に濃染した買が認められ，その下層には 


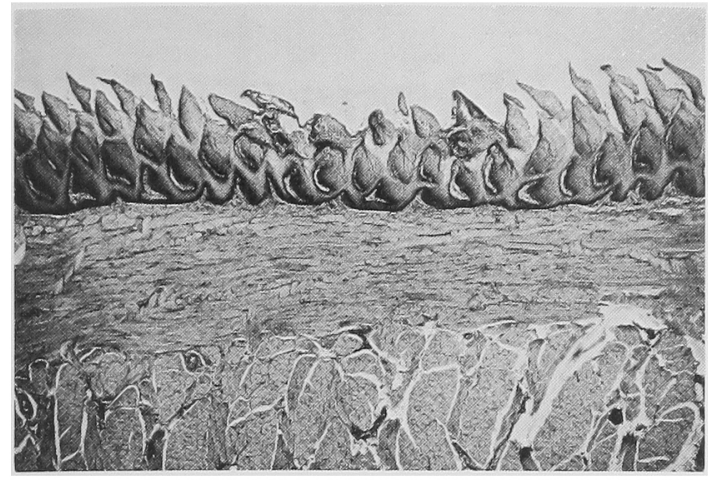

写真 7 I 群 (5 watts，0.2 秒) のレーザー照射直 後の所見 $(H-E$ 染色, $\times 40)$

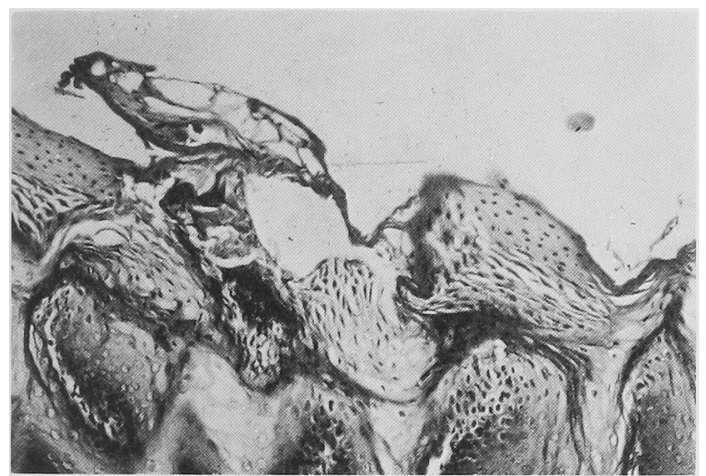

写真 8 I 群 (5 watts, 0.2 秒) のレーザー衫射直 後の所㒻 $($ H-E 染色, $\times 200)$.

細胞が細長く変形し，核が濃染・濃樎した部分や上皮細 胞が膨化した所見が認められる（写真 $7 ， 8$ ）.

II群 : 粘莫上皮の組織欠提はI群より深く，組織欠損 辺縁部の上皮勫胞は核が消失し好酸珄色素に濃染した層 が認められる，その下層では，細胞妿細長く変化し，組 織欠損の表面に平行に配列した層がみられ，核は漂染・ 濃縮している。ささらに組織欠損の表面より深部の上皮細 胞では上皮細胞が膨化した所見を認める，基底細胞層で は，細胞は毛状に変化し粘膜固有層との間には間隙が認 められる，粘瞙固有層は好塩基性色素に濃染し，線維の 変性を認める，筋層には変化は想められない（写真 9 ， 10).

II群 : レーザー照射により生じた組織欠損の辺縁部の 表層には，一部に炭化層を認める．組織欠損の辺縁部の 炭化層の外側の上皮細胞は細胞質が粗造となり，核が浱 染・謴縮した層を形成し，その外側には上皮細胞が王排 され，核が濃染・濃縮し，組織欠損部の表面に平行に配 列した層を認める。ささらに外側には上皮細胞が膨化し， 明るくみえる層が存在する，粘膜固有層は，好塩基性に 染色され，均一無構造となり，筋㬝は匤排され，一部で



写真 9 II 群 (15 watts，0.2秒) のレーザー炤射直 後の所見 $(\mathrm{H}-\mathrm{E}$ 染色， $\times 40)$.

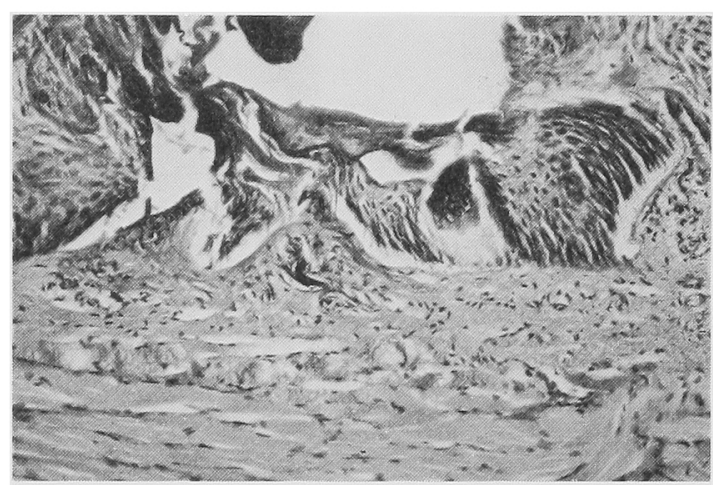

写真 10 II 群 (15 watts，0.2 秒) のレーザー炤射 直後の所見 $(\mathrm{H}-\mathrm{E}$ 染色, $\times 200)$.



写真 11 III 群 (20 watts，0.5 秒) のレーザー炤射 直後の所見 $(H-E$ 染色， $\times 40)$.

は欠損しているすのもみられる（写真11）.

II. レーザー照射後の創の経時的な組織学的所見 レーザー照射直後の口腔粘膜の組織学的変化に従い I， II， II 群について，経時的に観察した。 I 群 




写真 12 I 群 ( 5 watts， 0.1 秒) のレーザー照射 1 日後の所見 $(\mathrm{H}-\mathrm{E}$ 染色, $\times 40)$.

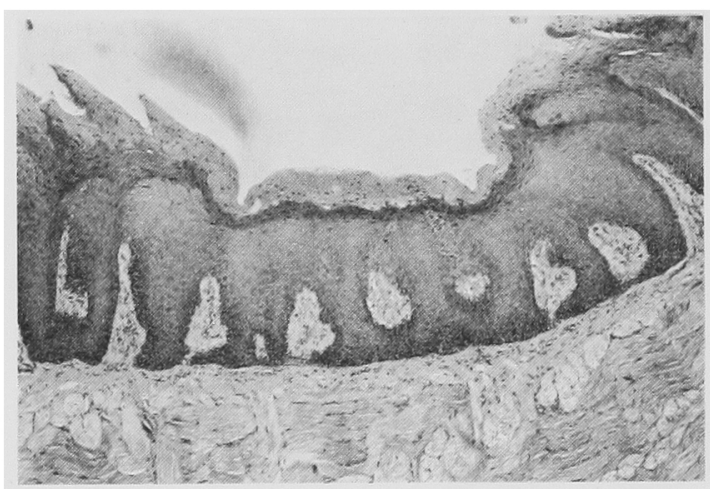

写真 13 I 群 (5 watts, 0.2 秒) のレーザー照射 3 日後の所見 (H-E 染色, $\times 100)$.

1 日後：照射部位に相当する部に，残存した粘膜上皮 の表層から隆起した好酸性に染まるカリフラワー状の上 皮塊が認められ，その基部には，好中球を主体とした軽 度の炎症性細胞浸潤および赤血球が認められる。また粘 膜固有凮にも㪕度の好中球を主体とした炎症性細胞浸潤 が認められる(写真12).

3 日後：照射 1 日後にみられたカリフラワー状の隆起 物はみられず，照射部位の粘膜上皮表層はほぼ平坦にな り，好酸性に濃く染まる薄い錯角化層就よび好酸性に薄 く染まるやや厚い錯角化層によって稪われている。この 部は周囲の健常な粘膜上皮に比べやや陷凹しているが， 上皮細胞の修復は完了している。1 日後に悡められた粘 膜固有凰の炎症性細胞浸潤は認められない（写真13）.

5 日後：3日後と同様の所見である.

7 日後：照射部位の粘膜上皮の陷巴は認められなくな り，錯角化層に覆われた系状突起が多数認められ，正常 占背粘膜と同様の組䅧所見を昆している（写真14）.

II 群

1 日後：照射部位に一致して，琶北表層にカリフラワ



写真 14 I 群 ( 5 watts, 0.1 秒) のレーザー照射 7 日後の所見 (H-E 染色, $\times 40)$.



写真 15 II 群 (10 watts, 0.2 秒) のレーザー照射 1 日後の所見 (H-E 染色, $\times 40)$.

一状の上皮塊が認められ，その基部には好中球を主体と した強い炎症性細胞浸潤が認められる。その下層の瑓な 上皮層は一部に基底層を残して久損している，残存した 基底層の細胞は，核が消失し，好酸性にはぼ均一に染色 された無樯造な物質として観察される。その下層には好 中球を主体とした高度の炎症性細胞浸潤および赤血球が 認められる，炎症性細胞浸潤捛よび赤血球が認められ る. 炎症性細胞浸潤は一部では粘膜固有層から筋層に及 んでいる，組織欠損の辺縁部の上皮細胞は核が消失して おり，その程度は舌背表層に近い部で高度であり，粘膜 固有鹰に近くなるに従い軽度となり，基底層では正常な 上皮細胞が認められる，好酸性に染色されたはほ均一無 棈造な物質の下方で，組織久損辺縁部の最深部の粘膜固 有層との境界部には，前述した正常な上皮細胞層の先端 から上皮細胞が創の中央に向け侵人し出しているのが悲 められる (写真15).

3 日後：暨射部位の粘膜上皮の欠損していた部の上皮 化は完了しているが深い陷四を示し，その表面にはやや 厚い錯觕化屬が諗められる。上皮突起の形成はまたみら 


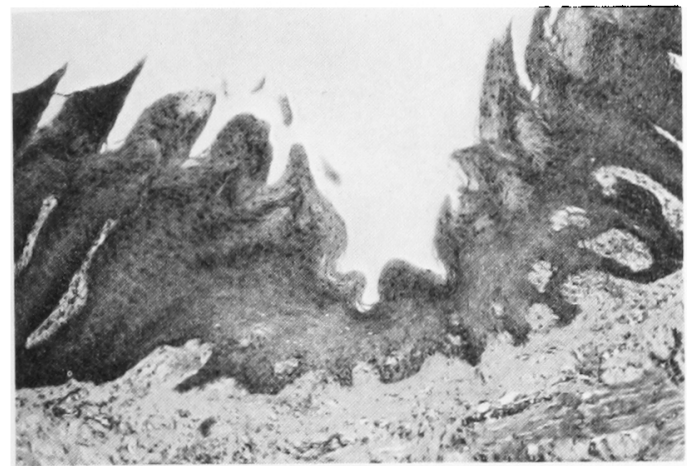

写真 16 II 群 (15 watts, 0.2 秒) のレーザー炤射 3 日後の所見 (H-E 染色, $\times 100)$.

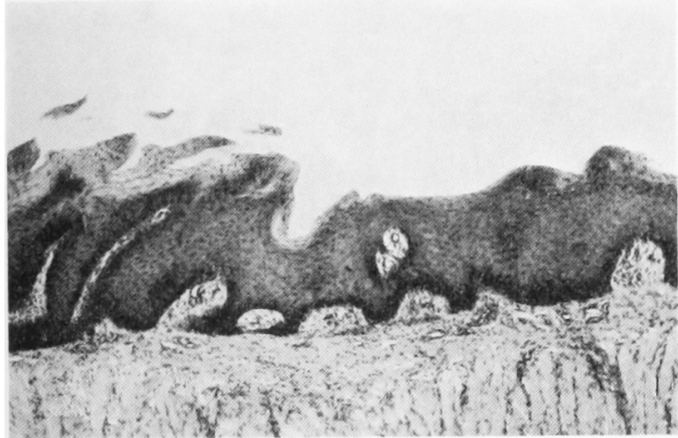

写真 17 II 群 (15 watts, 0.1 秒) のレーザー照射 5 日後の所見 (H-E 染色, ×100).



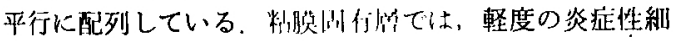



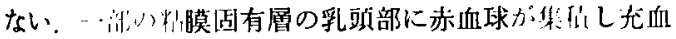
した所見が認められる（写真16）.

5 日後：3 日後の所見に比へ，判膜固有曆の炎症性細

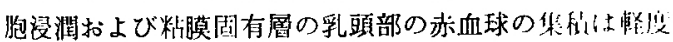
となっている。粘膜上兴の烦面で軽度の凹山がみられ るが，企体として上皮曆の厚さは一定となっている。そ の他には 3 日後の変化と比へ，とくに異なるところは認 められない（写真17)

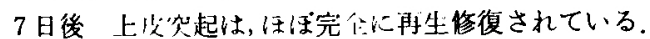
粘膜固有層には炎症性細胞浸潤は認められず荡薄な線維 化が認められる(写真18).

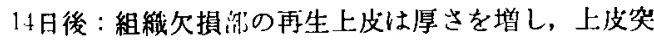

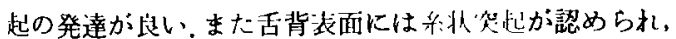
粘膜固有層の線維化がほぼ正常な状態であり，正常舌背 粘膜の像を呈している（写真19）。

纤群

1日後：约约部位に一致し粘瞙上皮が消失し，組緎火

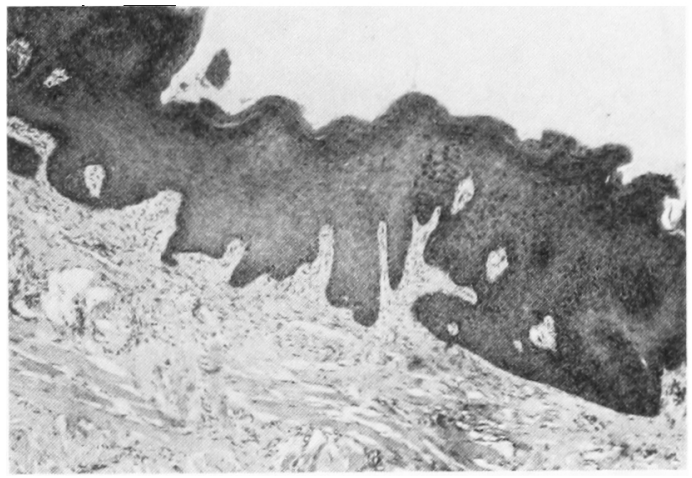

写真 18 II 群 ( 5 watts, 1.0 杪) のレーザー照射 7 日後の所見 $(\mathrm{H}-\mathrm{E}$ 染色, $\times 100)$.

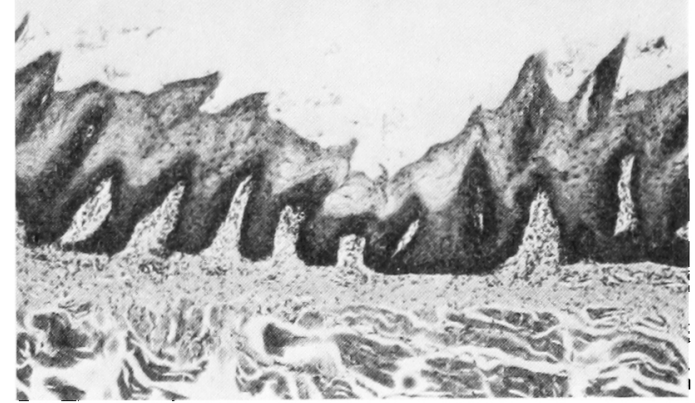

写真 19 II 群 (15 watts, 0.2 秒) のレーザー照射 14 日後の所見 (H-E 色, $\times 100)$.

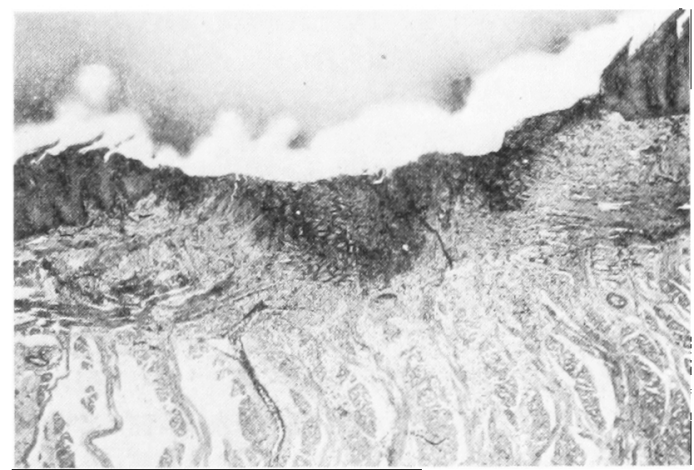

写真 20 III 群 (20 watts, 0.5 秒) のレーザー昭射 1 日後の所見（H-E 染色， $\times 10)$.

損が形成されている，組織欠損の底面表層ははほばー・に 好酸性に桨们され，好中球を主体とした高度の炎应性細 胞浸潤扰よび赤血球を認める。組䋐欠損の底面の下部で は，筋風の浅部は断裂し好酸性に染色され，核は消失し

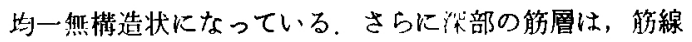




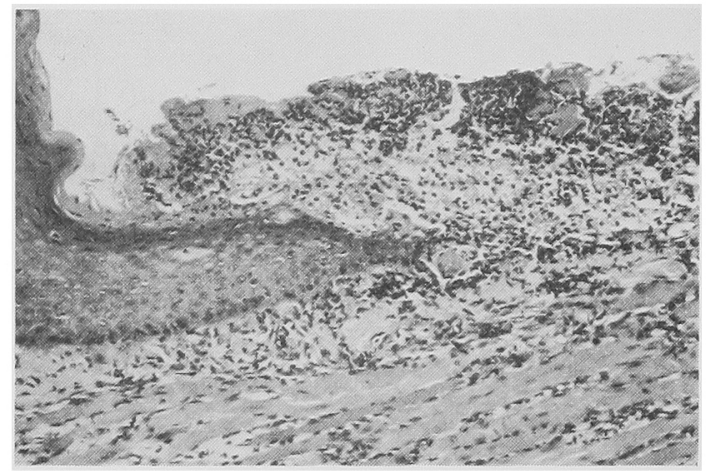

写真 21 III 詳 (20 watts, 0.5 秒) のレーザー炤射 3 日後の所見 (H-E 染色, $\times 200)$.

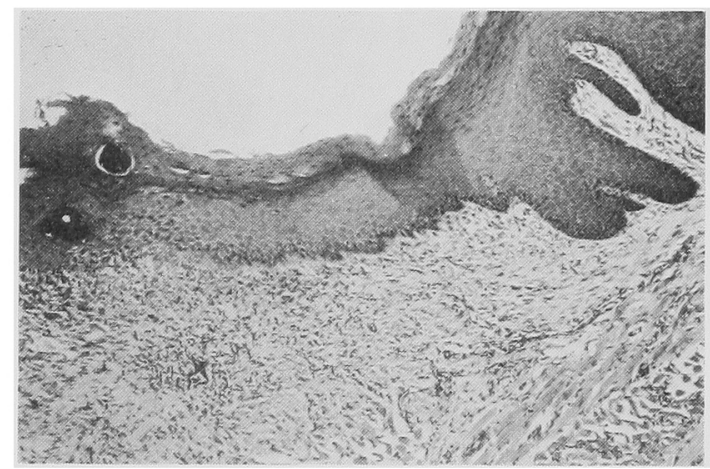

写真 22 III 群 (20 watts, 0.5 秒) のレーザー昭射 7 日後の所見 $(H-E$ 染色， × 100).

維の走行に压迫されたような乱れが認められるが断裂は みられず，核の消失も認められない，辺縁部の上皮から の上皮の侵入は認められない（写真20).

3 日後: 組織欠損部の底面表層には, 好酸性に注济均 一深色された線維素の出現が認められ，好中球を主体 とした高度の炎症性細胞浸潤が認められる，筋層内にも 高度の炎症性細胞浸潤が認められる. 組織欠損の辺縁部 の上皮凲は, 創の中央に向け組織欠損の底面に侵入して いる(写真21).

5 日後: 3 日後とほ注同様, 組織欠損の底面表層には 好中球を主体とした高度な炎症性細胞浸潤を認めるが。

3 日後のものに比べその程度は軽度である，䇨層内にる 高度の炎症性細胞浸潤を認めるが，3 日後に比べて軽度 である. 創の中央に向けての上皮化は 3 日後のそれと比 ベるとさらに進行している。

7 日後: 組織欠損部の上皮化は注注完了しているが。 粘膜上皮の厚さ情く，上皮突起の形成も認められな い. 上皮層直下には軽度の好中球を主体とした炎症性細 胞浸潤を認め，線維芽細胞が筋層の欠損部に侵入してい るのが誌められ，さらに筋層から再生粘膜上皮に向け血

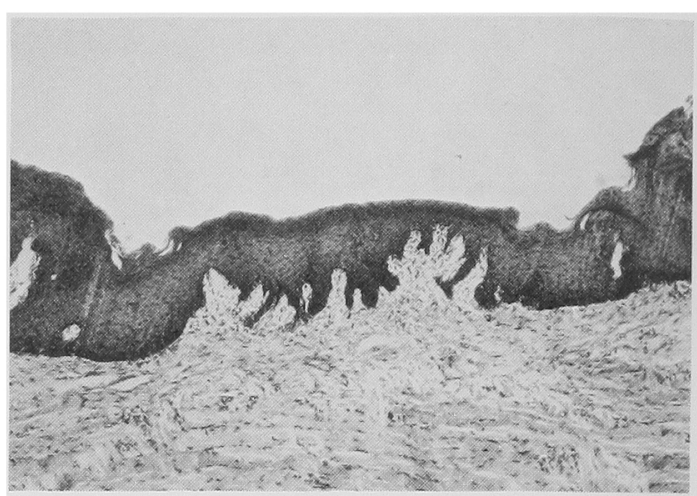

写真 23 吕群 (20 watts, 0.5 秒) のレーザー照射 14 日後の所見 $(\mathrm{H}-\mathrm{E}$ 染色, $\times 100)$.

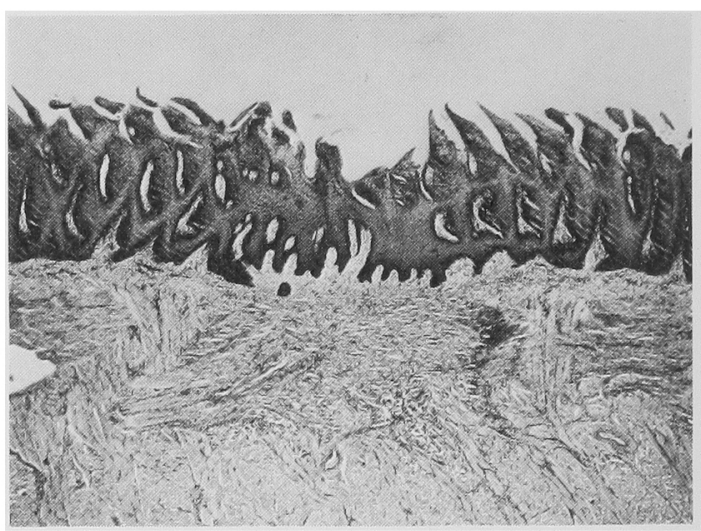

写真 24 III 群 (20 watts, 0.5 秒) のレーザー炤射 21 日後の所見 $(\mathrm{H}-\mathrm{E}$ 染色, $\times 40)$.

管の新生も熹められる(写真22).

14 日後：組織欠損部の上皮化は完了しているが，粘膜 上皮の厚さは薄い，上皮突起の形成を認めるが，その程 度は不完全である。上皮層直下では線維芽細胞が筋層の 欠損部に侵入しているが炎症性細胞浸潤は認められない (写真23).

21 日後：組織欠損部の再生上皮は厚さを增し，上皮突 起の発達が良く，舌背表面には多数の糸状突起が䁲めら れる．照射中心部の粘瞙固有風は周团と比ぺやや細かい 結合組織性線維よりなっているのが認められる（写真 24).

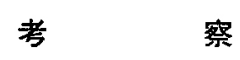

LASER $\$$ light amplification by stimulated emission of radiation の頭文字をとってできた合成語である. 1960年 Maiman23がルビーレーザーの発振に成功して以 来種々のレーザーが開発され，現在ではへリウム・ネオ ン.アルゴン，炭酸ガス等を代表とする気体レーザー， 
ルビー, Nd-YAG などの個体レーザー，その他，液体 レーザー, 半導体レーザーなど各種のレーザーが開発さ れ，その一部は実用に供されている。

レーザー光の特性として，(1) 位相がそろっている.

（2）指向性がよい（3）単色性にすぐれている.（4）高 輝度である等があげられる6)、レーザーは開発当初より その特性を利用して，広範囲の分野で応用され，臨床医 学への応用も,さかんに行われている.

1964年 $\mathrm{Patel}^{3)}$ により開発された炭酸ガスレーザーは, $10.6 \mu \mathrm{m}$ の遠赤外線領域の波長を有し, 生体軟組織に対 する吸収係数が大さい.

光の吸収については Lambert の法則がある。すなわ ち入射光の強度をlo, 透過光の強度を I, 吸収係数を $\sigma$, 吸収物質層の厚さをd とすると

$\log _{\mathrm{e}} 1 \mathrm{o} / \mathrm{I}=\sigma \mathrm{d}$ が成り立つ.

一方，入射光強度の $90 \%$ が吸収されてしまう光路層の長 さLを光消散長といい、これは光の吸収されやすさの目 安の指標とされている. この光消散長 $\mathrm{L}$ と吸収係数 $\sigma$ と の間には

$\mathrm{L}=1 / \sigma \log _{\mathrm{e}} \mathrm{lo} / \mathrm{I}=1 / \sigma \log _{\mathrm{e}} 100 / 10=1 / 0.434 \times \sigma$ (ただ し $\left.\log _{10} \mathrm{e}=0.434\right)$ の関係式が成り立つ4). すなわち $\sigma$ が 大きいほどLは短くなる，炭酸ガスレーザーは，この吸 収係数 $\sigma$ が大きいことから，生体組織に照射した場合ご く表層で光が吸収されてしまい，周囲への影響が少ない ことが考えられる.

レーザーによる治療は，直接組織に接触することな く, 組織の切断, 蒸散が可能であるといら特徵を有する が，従来の鋼刃メス，電気メスに比べ，切離創の深さの 調節が困難であるといら点がある。一般に口腔粘膜は 皮膚と比べると薄く，その直下に骨などが存在し，また 口腔内には歯が植立しているなどの特殊な形態を有して おりこれら組織を損傷しないためにも，レーザーを口 腔内に適用する場合にはより正確な深さの調節が要求さ れる，炭酸ガスレーザー照射による皮虞やその他の組織 に対する影響についての研究は数多いが，口腔粘膜に照 射した場合の組織学的変化を詳細に検討した研究は少な く，とくにその創傷治瘉過程を経時的に観察した研究は 殆どないしたがって，この点を明らかにすることは， 炭酸ガスレーザーをロ腔領域へ適用するにあたり臨床応 用上最も重要であり, かつ必要不可欠な問題と考えられ る。そこで著者は，家鬼の舌背を用い，炭酸ガスレーザ 一照射による即時的変化である照射直後の組織欠損の深 さ，照射創の状態について，肉眼的および組織学的に観 察するとともに, 治㾑過程を知る目的で, 経時的に組織 学的所見の詳細な検討を行った。 その結果について以下 のような項目にしたがって考察する。

\section{1. 欠損部の深さについて}

炭酸ガスレーザー照射による組織欠損部の深さを計测 した報告は少ない.Adrian【(1979) マ) は炭酸ガスレーザ
ー (Coherent 社裂 System 400 Surgical Laser(ß) を用 い, 5 watts, 10 watts, 20 watts の出力条件でおのおの 0.5 秒, 4 回, 計 2 秒間焦点位で, 赤毛猿の歯肉, 舌下 面，口唇粘膜に照射し，組織忉料を採取し10\%リン酸緩 衝ホルマリン液で固定後組織切片を作製し, 組織久損の 深さを計测している. 計测結果の平均值は, 出力 5 watts で直径 $1.7 \mathrm{~mm}$ ，欠損部深さ $0.20 \mathrm{~mm}, 10$ watts では直 径 $1.7 \mathrm{~mm}$, 欠損部深さ $0.29 \mathrm{~mm}, 20$ watts では直径 $2.14 \mathrm{~mm}$, 欠損部深さ $0.48 \mathrm{~mm}$ であったと報告している. 著者の実験と実験機器が同じである Adrianの報告と， 本研究の結果とを比較すると, Adrian は出力 5 watts, 10 watts, 20 watts の条件でおのおの 2 秒間の照射を行 い, 前述した結果を得ているが, 本実験では, 出力 5 watts 群: 1.0 秒; $423 \pm 197 \mu \mathrm{m}, 10$ watts 群: 1.0 秒; $687 \pm 357 \mu \mathrm{m}, 15$ watts 群: 1.0 秒; $949 \pm 311 \mu \mathrm{m}, 20$ watts 群 : 1.0 秒; $1374 \pm 244 \mu \mathrm{m}$ の結果を得, 照射出力 5 watts, 10 watts, 20 watts, おのおの照射時間 1 秒の照 射条件で，すでに Adrianに比べて深い值を示していた。 この原因として，計測法の違いが考えられる. Adrian は欠損の深さを，組織材料を採取し，10\%リン酸緩衝ホ ルマリン液で固定後, 組織切片を作製し計測しているた め, 固定, 包埋, 染色等の操作による組織の収縮变形が 測定値に影響を及ぼしたものと推察される。一方，著者 はレーザー照射直後の舌背を印象採得し, 舌背模型を作 製し, ミクロン深さ高さ測定機(日商精密光学丁業社製) を用い，舌背模型の被検査部位表面が測定台に平行にな るよらに固定し，同一籄所を 5 回测定した。この測定法 の精度について，天笠 (1973) $)^{5}$ は棶肉スティップリング の再現率を，ストマトスコープによる観察結果と各種印 象材で印象採得した歯肉の石膏模型の観察結果との比較 から，印象材ではシリューンラパーが最も優れ，98土 1.7\%の再現率を示したとし，石育の比較では，表面ア ラサ標準片としてキャリブロック・マークII の $11 \mu \mathrm{m}$ Romax 表面を用い, 得られた試料模型表面の微細凹凸を 万能投影機・光切断表面アラサ検査装置で観察計測し, 試料表面の微細部再現率を求め, 超硬石倠は $98.8 \%$, 硬 石膏は $93.8 \%$ ，普通石膏は $18.8 \%$ 再現率であったと 報告している。本実験では，この天笠の結果に基づき， 印象材としてシリコーンラバーを，石喜は硬石高を用い た 本法は生体の凹凸を計湘する際, 再現性に䨤れた方 法であり，本実鈳の計測結果は，その高い精度と再現性 からほぼ実測值と考えられ，採取組織の固定，包埋，染 色等の操作による組織の収縮変形が大きいと推定される Adrianの計测結果と，違いが出たものと考えられる.

\section{2. 照射直後の変化について}

レーザー照射直後の照射部の肉眼的钼察の結果では, 以下の 2 群に分けられた。

1 群：組織の実質欠損を認めず，照射部位に一致して 組織表面が円形白色に変化するか。 または，一部に炭化 
物を認める群 ( 5 watts・0.1秒・0.2秒, 10 watts・0.1秒 照射群)

2 群：組織の実質欠損を認める群，すなわち，照射部 位に一致して組織欠損が存在し, 組織欠損の周辺部に隆 起を認め, 組織欠損の底面が舌背表面に向かい凸の形態 を示す倒円錐形の組織欠損を認める群 (5 watts・0.5 秒・ 1.0 秒, 10 watts 0.2 秒・ 0.5 秒 $\cdot 1.0$ 秒, 15 watts 0.1 秒・ 0.2 秒・ 0.5 秒 $\cdot 1.0$ 秒, 20 watts 0.1 秒・ 0.2 秒 $・$ 0.5 秒 $\cdot 1.0$ 秒照射群)

Hall $5^{8)}$ は, 高速度カメラを用い, 炭酸ガスレーザー 照射部位の観察を行い。組織の欠損が生じる温度は水の 沸点であると報告している，本実験の結果から，細胞内 の水が沸騰し細胞が破壊される温度, すなわち $100^{\circ} \mathrm{C}$ 以 上に組織の温度が上昇するのに必要なレーザーの照射ェ ネルギー量は, 直径 $2 \mathrm{~mm}$ の円形の照射部位では, 10 watts $\times 0.1$ 秒 $=1$ Joul から 10 watts $\times 0.2$ 秒 $=2$ Joul の 間にあると考えられた。

照射部位の組織欠損について, Mihashi $5^{9,10)}$ は 15〜 $20 \mathrm{~kg}$ の雑犬の舌下面に炭酸ガスレーザーを照射し（照 射条件 : 20 watts・0.44秒 (8.8 Joul)) 照射直後の 組織 欠損部の形態を肉眼および走查電子顕微鏡で観察してい る。それによると肉眼的には，著者の観察結果と同様で 組織欠損の周辺部が円形，白色に変化し，かつ境界部が 隆起し, 組織欠損の底面の中央部が軽度に凸の倒円錐形 の組織欠損を示し（Mihashi らは crater と表現してい る), 組織欠損辺縁部では，炭化物の付着を認めており， また，走査電子顕徵鏡的には，(1) crater 辺縁部を内側 より観察したところ, 組織内水分の蒸発に基つく多数の 2 次小孔を認め, また上皮は下部組織より剥離, 隆起 し，その先端部では大小㥞々の 2 次小孔とともに一部に ひびわれ，亀裂を認める。上皮下の下部組織はあたかも 溶岩が固まったような様相を邑している。（2）crater 辺 縁部剝離上皮外側面では，伈々の細胞は識別できず，細 胞表面の microridge は消!失しょり表面は不規則である.

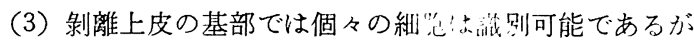
明確ではない 細胞全体として縮小倾向と音:している。 細胞表面の microridge は消失し，そり表亚:な不規則で ある。（4）さらに外側部においては，個々の細胞は明確 に識別され得る。おの括のの細胞は拡大しているが，核 は反対に縮小し，表面より幾分突出する傾向を呈してい る. 細胞の境界部は個々の細胞の拡大に伴いいくぶん盛 り上がっている，細胞表面の微細構造は比較的良く保た れているが，らね状の microridge は認められない以 以 上の変化は crater の辺縁より $500 \mu \mathrm{m}$ 内外に認められ るとしている。本実験では走查電子顕微鏡による推察は 行わなかったが、ミクロン深さ高さ測定機を用い，石高 模型の被検査部位表面を钼察し，境界部に小隆起を钼察 できた。

本研究では炭酸ガスレーザー照射直後の変化を組織学
的に観察した結果，次の 3 群に分けられた.

I 群 : 組織学的変化が粘膜上皮の有棘層にのみ限局 し，基底層およびその深部に変化のないもの

II 群 : 組織学的変化が基底層, 粘膜固有層に及ぶが, 筋層には変化のないもの

III群 : 組織学的変化が筋層に及ぶもの

レーザー光の生体に対する作用機序については熱, 王 力, 光, 電磁界の 4 つが考えられているが; 炭酸ガス レーザー照射の場合の生体組織への作用機序として, Litwin ら (1969) ${ }^{11)}$ は熱作用をあげており, その障害の 程度は炭酸ガスレーザー照射の出力, 照射時間および power density により決定されると報告している。 また Hishimoto ら (1975) ${ }^{12)}$ は，炭酸ガスレーザー照射によ り作製した，皮盧の切開創の組織学的所見は， 2 度ない し 3 度の熱傷の組織学的所見と同じであると述べてい る. 本実験でも，I群で残存した粘膜上皮は，上皮細胞 の核が消失し好酸性色素に濃染した層が認められ，その 下層には細胞が細長く変形し, 核が濃染・濃縮した部分 や，上皮細胞が膨化し，さらに II 群の基底細胞層では， 細胞は毛状に変化し粘膜固有層との間には間隙が認めら れた。これらの所見は熱傷の組織学的所見とよく類似す るものである ${ }^{13)}$.

渥美 (1969) ${ }^{14)}$ は McGuff の報告を引用し，レーザー 光が生体に対して熱の効果として作用するには，(1) $200 \sim 1,000^{\circ} \mathrm{C}$ 位の温度上昇が数 $\mathrm{ms}$ のごく短い時間に

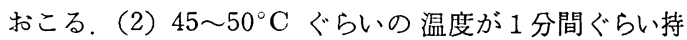
続する，とい52つのメカニズムが考えられるとしてい るが，熱の上昇には，（1）爇伝導度，（2）比熱，(3) 熱 伝導の方式, (4) 弾性, (5) 含水量, (6) 周囲の環境, （7）レーザー光の反射，（8）蒸発熱，（9）溶解熱などの 各種の因子が関係するのでこれらを総合した視点から 熱の生体組織への効果を詳細に検副する必要があると述 ベている。

著者の実験では，照射直後の組織変化は，熱作用の他 に群にみられたよらに筋增が王迫された形態を示した ことから，王作用の関与も考えられた。

\section{3. 創傷治瘾について}

口腔粘膜の炭酸ガスレーザー照射後の口腔粘膜の創傷 治瘉過程に関した報告は少ない Fisher ら (1983年) ${ }^{15)}$ は, ビーグル犬の煩粘膜に, 直径 $2 \mathrm{~cm}$ の円形の粘膜欠 損創を鋼刃メスおよび炭酸ガスレーザー（出力 10 watts, 20 watts）を用いて作製し，経時的に組織学的観察を行 い, 肉腿的には鋼刃xスによる創は瘢痕収縮も高度で, 48日経過後も瘢痕が認められたが, 一方, 炭酸ガスレー ザーによる創は照射後28日後には上皮化は完了し, 創と 健常組織との境界が不明膫で, 洀痕収縮も軽度であった と報告している。ぬた組織学的には炭酸ガスレーザー照 射後の創において，照射直後では，創の表面は好塩基性 色素に染色された均一な凝塊がみられ，その下層にコラ 
ーゲンが Eosin に染色された薄い層を認めたが，多核白 血球はどの層にもみられなかったと述べ，線維性凝塊は 照射後短期間みられ，7 日後にはその厚さが最大にな り，この内部に多核白血球がみられ，その下層にみられ る炎症性細胞浸潤でも多核白血球が主要細胞であり，照 射後 4 日後には炎症性細胞の浸潤が最大になり，血管の 内皮細胞の増殖が顕著になるとし, 上皮細胞の創への侵 入は照射後 4 日後に明らかになり，28日後には完了した と報告している. Mihashi ら²) 15〜20 kg の雑犬の舌 下面に炭酸ガスレーザーを照射し（照射条件：20 watts・ 0.44 秒 (8.8Joul)) 照射後の創の治癒過程を観察し, 照 射 1 時間後では創周囲の小血管, 毛細血管に充血が認め られ, 赤血球の溢出, 好中球の遊出もみられ，48時間後 には好中球を主体とした炎症性反応が著明で, 壊死組織 は好中球で取り团まれて和り，さらに周辺部より上皮細 胞の増生がみられると報告している，1週間後には炎症 性反応は減弱し, その主要細胞は単核球となり, 新生血 管, 線維芽細胞が組織内に多数認められ, 上皮細胞での 創の被覆は䚾とんど完了している。2 週間後では創は完 全に上皮で被覆されている。止突起は形成されている が，正常に比べ短い上皮下には単核球を主体とする炎 症性細胞, 線維芽細胞が楔状に管線維間に侵入してい る. 3 週間後では上皮突起は， 2 週間後と同様に正常組 織に比べ短い, 上皮下には単核球, 線維芽細胞が筋線維 間に侵入し散在していると報告している。口腔粘膜以外 では，大久保 ${ }^{16)} は$, 声带粘膜に炭酸ガスレーザーおよび 鋼刃メスを用い, 犬の声帯膜様部全長にわたって粘膜固 有層浅層のみの切除を行ったものをI 型, 粘膜固有層浅 層より深く，上皮と筋層との中間まであるいはそれ以内 の切除を行ったものをII 型, 粘膜固有層全層に及ぶ切除 を行ったものを型に分け，治瘉過程を検討している. それによるとレーザー照射侧では，I型は 2 週で創面は 全て再生上皮により被㠅され，II 型では 2 週で損傷部の 80〜 90\% は再生上皮で㠅われ，3 週では完全に被澓さ れ，再生上皮直下にはきわめて薄い結合織の層が存在す るのみで，炎症反応はみられず，林型でも創面は 3 週で 再生上皮で被覆され炎症反応は消失し，さらに炎症反応 はレーザー側では 1 週で消退するのに比べ, メス側では 2 週後まで認められるものが多く，その程度もレーザー 側に比較して鋼刃メス側のほうが大であったと報告して いる.

本実験ではレーザー照射直後の組織学的変化に従い3 群に分けて，レーザー照射後の創傷治瘉過程を組織学的 に観察した

I 群 : 照射直後の組織学的変化が粘膜上皮の有栜㬝に のみ限局し, 基底層およびその深部に变化が認められな かったもの (5 watts・0.1秒・0.2秒・0.5秒, 10 watts ・ 0.1 秒照射群)

II 群 : 照射直後の組織学的変化が基底層, 粘膜固有層
に及ぶが，筋層には変化が認められなかったもの（5 watts 1.0 秒, 10 watts 0.2 秒, 15 watts 0.1 秒・ 0.2 秒, 20 watts $\cdot 0.1$ 秒照射群)

III群：照射直後の組織学的変化が䇗層に及んでいたも の (10 watts 0.5 秒・1.0秒, 15 watts $\cdot 0.5$ 秒・1.0秒, 20 watts $・ 0.2$ 秒・ 0.5 秒・1.0秒照射群）

I 群では照射後 1 日では，好酸性に染色されたほぼ均 一のカリフラワー状の隆起物の基底侧内部に, 好中球を 主体とした軽度の炎症性細胞浸潤を認め, また粘膜固有 層にも軽度の炎症性細胞浸潤を認めた。 3 日後にはすで に粘膜上皮表層は平坦になり, 軽度の陥凹を示していた か上皮細胞の修復は完了し, 粘膜固有層の炎症性細胞浸 潤も認められず，7日後には上皮層の伯凹もみられなく なり，照射後早期に創傷治瘉が進行したと考えられた。

II 群では照射後1日では，好酸性に染色されたほぼ均 一な物質内に好中球を主体とした著明な炎症性細胞浸潤 が認められ，一部は筋層に及んでいた。しかし組織欠損部 の辺縁部の上皮細胞からの上皮化がすでに始まり，3日 後には早くも上皮化は完了していた。しかし上皮突起の 形成はまだみられず，粘膜上皮の厚さも薄く，また上皮 細胞の配列は舌背表面に平行であった。粘膜固有層では 炎症性細胞浸潤を軽度に認めたが，筋層には炎症性細胞 浸潤を認めず，粘膜固有層の乳頭部に充血を認めた。 5 日後では 3 日後にみられた粘膜固有層の炎症性細胞浸潤 扣よび粘膜固有層の乳頭部の充血は軽度となっていた。 7 日後には上皮突起がほぼ形成され，14日後では上皮突 起の発達も良好で創賃治癒は完了していた。

III群では照射後1日では明らかな組織欠損が监射部位 に形成されており，また好酸性に染色された注均一な 物質内に好中球を主体とした高度の炎症性細胞浸澗を浔 めたが，II 群にみられた組織火損部の辺縁部の上皮細胞 から侴の中央に问けての上文化はみられず，組䄉灭損の 底面で，その表層の浅い部の㥐層は率裂し，好酸性に染 色され，核は消失し均一無構造になっていた。さらに深

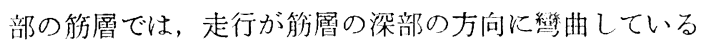
が，筋層の断裂や核の消失は認められず，笳層が压迫さ れたよらな組織像を呈していた。3日後でも組織欠損部 に，好酸性に染色されたほぼ均一な物質内に好中球を主 体とした高度の炎症性細胞浸潤が認好られ，また，筋層内 にも高度の炎症性細胞浸潤が認められた。組織欠損部の 辺縁部の上皮細胞から上皮化は開始していた。 5 日後で は組織学的所見は3日後とほ汪同様であり, 炎症性細胞 浸潤は軽度になっていたが，上皮化はまだ完了していな かった７日後には組織欠損部の上皮化は完了している が，粘膜上皮の厚さは薄く，上皮突起の形成も涩められ ない上皮下には，好中球を主体とした軽度の炎症性細 胞浸潤を認め，筋層の伯凹部に楾維芽細胞が認められ， 線維組織が形成され，また筋廨より再生粘膜上皮直下に 向け，血管の新生がみられた。14日後でも粘暯上皮の厚 
さは健常な粘膜上皮に比べ薄く，再生粘膜上皮には上皮 突起の形成は認められたが，その程度は不完全であり， 炎症性細胞浸潤は認められなかった。 21 日後には, 組織 欠損部の再生粘膜上皮層は厚さを増し，上皮突起の発達 も良好であった。

本実験の成績と Mihashi ら99 の結果とを比較すると, 照射条件からは本実験の III群が Mihashi らの実験条件 に相当すると考えられる．本実験において 3 日後に組織 欠損の辺縁部の粘膜上皮から上皮化が開始し，7日後に は組織欠損部が上皮細胞で被覆されていたが，Mihashi らの結果では 4 日後に組織欠損部の辺緑部の粘膜上皮か ら上皮化が開始し，7 日後には上皮細胞での創の被覆は ほとんど完了していたと報告し，本実験の結果と同様の 所見であった。一般に口腔粘膜の欠損創の治癒過程につ いては, 粘膜上皮拈よび上皮下の結合組織が関与し，粘 膜上皮では最初の 24 時間内に上皮細胞の欠損創への侵入 が始をるとされている ${ }^{17)}$. すなわち欠損創周团の健常な 粘膜上皮もしくは小唾液腺等の附属器の細胞からの侵入 がみられるといわれている。 また，侵入する上皮細胞の 形態は, 健常な上皮細胞が四角形であるのに比べ, 細く かつ長い形態を示すとされている ${ }^{17)}$. 本実験に怙いて も，組織欠損創が上皮で被覆された初期には，上皮細胞 は舌背表面に平行に扁平で細長い形態を示した。 上皮細 胞の欠損創への侵入に影響する因子としては，(1) 細胞 の移動を促進する牽引力が細胞間にあること（2）上皮 細胞が細胞外因子と接触していること。の 2 点が挙げら れている ${ }^{17)}$ 本実験ではII群においては1日後に上皮細 胞の欠損創への侵入が観察され，3 日後には上皮化が完 了していたが，上皮の侵入速度は， 口腔粘膜では 0.5 $\mathrm{mm}$ であるとの報告もあり ${ }^{18)}$, 本実験の欠損創の直径が $2 \mathrm{~mm}$ と小さいことから，早期に上皮化が完了したもの と思われる. Fisher ら ${ }^{15)}$ は28日後に上皮化は完了したと 報告しているが，Fisher らの実験では口腔粘膜の欠損が 直径 $20 \mathrm{~mm}$ と大きいことに起因していると考えられる。 しかし本実験の II 群および Mihashi ら9の結果では，上 皮細胞の欠損創への侵入が 3 日後ないし 4 日後に初めて

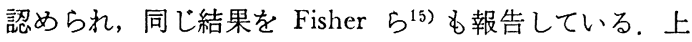
皮細胞の創への侵入の遅延が上皮化の遅延関与してい ると考兄られるが、これは群では欠損創周囲の上皮細 胞に変性が高度に認められたことの影響と思われる。

Fisher $5^{15)}$ 打よび大久保 ${ }^{16)}$ は, 実験的に粘膜欠損創を 炭酸ガスレーザーおよび鋼刃メスで作製し，その治瘾過 程を比較しているが，両者とも，炭酸ガスレーザーで作 製した創では洀痕の形成は鋼刃メスで作製した創に比較 し軽度であったと報告している。本実験でも，組織学的 変化が筋層に及ばなかった II 群では，粘膜固有層の線維 化が軽度であったことから，粘膜固有層までの炭酸がス レーザーによる切除では, 術後の洀痕形成が従来の鋼刃 メスによる切除に比べ，少ないことが示唆された。
しかし，笳層に組織学的変化が及んだ群では上皮化 の遅延， 欠損した筋風の線維組織による置換がみられた ことから，筋層に及ぶ切除を行った際には 1 期的に縫合 閉鎖するか，皮㲊もしくは粘膜による創の被覆が必要で あることが推察された。

\section{結語}

炭酸ガスレーザー照射による口腔粘膜の組織欠損の滐 さ, 照射直後の組織学的変化拈よび治疮過程を知る目的 で，家鬼の舌背を用いて実験を行い次の結果を得た．

1 炭酸ガスレーザー照射直後の肉眼的変化では, 直 径 $2 \mathrm{~mm}$ の円形の照射部位で $1 \mathrm{Joul}$ までの照射では, 照射部位に一致して舌背表面は円形に脱色され，白色に 変化するか，一部に炭化物を認めるのみであったが， 2 Joulをこえる照射では，照射部位に一致した組織欠損を 認めた。

2 組織欠損の形態は, 組織欠損の辺縁部之組織欠損 の周辺部の境界部で組織欠損の周辺部に比べ軽度の隆起 を伴う倒円錐形の形態を示し, 組織欠損の底面の中央部 では小隆起が観察されたものもあった。

3 炭酸ガスレーザー照射による組織欠損の深さの平 均值は, 5 watts 群: 0.1 秒; $0 \mu \mathrm{m}, 0.2$ 秒; $195 \mu \mathrm{m}, 0.5$ 秒 ; $265 \mu \mathrm{m}, 1.0$ 秒; $423 \mu \mathrm{m}, 10$ watts 群: 0.1 秒; 63 $\mu \mathrm{m}, 0.2$ 秒 $; 101 \mu \mathrm{m}, 0.5$ 秒 $; 419 \mu \mathrm{m}, 1.0$ 秒 $; 687 \mu \mathrm{m}$, 15 watts 群: 0.1 秒; $139 \mu \mathrm{m}, 0.2$ 秒； $342 \mu \mathrm{m}, 0.5$ 秒; $607 \mu \mathrm{m}, 1.0$ 秒; $949 \mu \mathrm{m}, 20$ watts 群: 0.1 秒; $205 \mu \mathrm{m}$, 0.2 秒；322 $\mu \mathrm{m}, 0.5$ 秒 $; 731 \mu \mathrm{m}, 1.0$ 秒 $; 1,374 \mu \mathrm{m}$ で あり，同一出力では照射時間に比例して欠損の深さが增 していた。

4 炭酸ガスレーザー照射直後の組織学的変化は，照 射条件により

1) 5 watts $\cdot 0.1$ 秒 $\cdot 0.2$ 秒 $\cdot 0.5$ 秒， 10 watts $\cdot 0.1$ 秒 照射群では, 組織学的変化が粘膜上皮の有栜層にのみ限 局し，基底層およびその深部に变化が認められなかっ た。

2) 5 watts 1.0 秒， 10 watts $\cdot 0.2$ 秒 $\cdot 15$ watts 0.1 秒・0.2秒, 20 watts 0.1 秒照射群では, 組織学的変化 が基底層, 粘膜固有層に及ぶが, 筋層には変化が認めら れなかった。

3) 10 watts $\cdot 0.5$ 秒 $\cdot 1.0$ 秒， 15 watts 0.5 秒・1.0 秒, 20 watts 0.2 秒・0.5秒・1.0秒照射群では, 組織学 的変化が筋層に及んでいた。

5 炭酸ガスレーザー照射後の治喻過程は, 照射直後 の組織学的変化に従い，3群に分けて観察したところ， 各群により治瘾過程に相違が認められた。すなわち, 組 織学的变化が粘膜上皮の有棘層にのみ限局した群では, 7 日で組織の修復は完了し, 組織学的変化が基底層, 粘 膜固有層に及ぶが，朌愿には変化が認められなかった群 
では，14日で組織の修復は完了していた。しかし組織学 的変化が筋層に及んだ群では，組織の修復に21日を要し た.

6 以上より，炭酸ガスレーザー照射によるロ腔粘膜 病変の治療では, 一定の深さで病変を除去することが可 能であり，また病変が竻層に及ばないものでは，組織の 修復が早期に完了することから，口腔外科臨床では有用 な治療手段であることが示唆された。

稿を終えるにあたり，終始ご留簏なこ指導を晹わりま した, 東京医科断科大学迷学部第 1 口腔外科学教室主 任, 塩田重利教授に心から感謝の意を表しますまたご 校閲，こ教示を晹わりました，東京医科菌科大学歯学部 口腔病理学教室主任，山本筷教授に深謝いたします。 さらに本研究を進めるにあたり終始ご指導，ご鞭撻を晹 わりました，東京医科歯科大学歯学部第 1 口腔外科学教 室, 橋本賢二助教授に感謝の意を表するとともに, 組織 欠損の深さ測定にご教示頂きました東京医科㮸科大学㮸 学部第 1 口腔外科学教室, 天笠光雄講師に深謝いたしま す。またこ援助，こ協力を賜わりました，東京医科茵科 大学菌学部第 1 口腔外科学教室, 旧第 5 研究室の諸先生, ならびに教空員各位に感謝いたします

なお本研究は, 昭和 54 年度交部省科学研究費の一部に より行われたものであり，本諭交の要旨は，第34回日本 口腔科学会総会（1980年 5 月，岡山）においてロ演発表 した.

\section{引用 文 献}

1）秋山洋：手術基本手技，第 1 版，医学書院， 東京, 1975, 11-13頁.

2) Maiman, T.H.: Stimulated optical radiation in ruby. Nature 187: 493-494 1960.

3) Patel, C.K.N.: Interpretation of $\mathrm{CO}_{2}$ optical maser experiments. Physical Review Letters 12: 588-590 1964.

4）渥美和彦編集：レーザー医学。基礎と臨床. 中山書店, 東京, $1980,27-40$ 頁.

5) 天笠光雄：健康拉よび病的歯肉の表面粗造性に
関する研究. 口病誌 40：428-456 1973.

6）松平維石：レーザーの基礎と実験。第 1 版，共 立出版, 東京, 1972, 4-5頁.

7) Adrian, J.C.: Effects of carbon dioxide radiation on oral soft tissues. An initial report. Milit Med 144: 83-89 1979.

8) Hall, R.R., Beach, A.D., et al.: Incision of tissue by carbon dioxide laser. Nature 232: 131-132 1971.

9) Mihashi, S., Jako, G.J., et al.: Laser surgery in otolaryngology. Interaction of $\mathrm{CO}_{2}$ laser and soft tissue. Ann NY Acad Sci 267: 2632931976.

10）三橋重信：炭酸ガスレーザー昭射による組織表 面構造の変化。走査電子顥微鏡による観察。日 耳鼻 80: 1483-1487 1977 .

11) Litwin, M.S., Fine, S., et al.: Burn injury after carbon dioxide laser irradiation. Arch Surg 98: 219-222 1969.

12) Hishimoto, K., Rockwell, R.J., et al.: Laser wound healing compared with other surgical modalities. Burn 1: 13-22 1975.

13) Moritz, A.R.: Studies of thermal injury. III The pathology and pathogenesis of cutaneous burns. An experimental study. Am J Path 23: 915-941 1947.

14）渥美和彦：レーザの医学への応用 (1). 医学の あゆみ 70: 362-366 1969.

15) Fisher, S.E., Frame, J.W., et al.: A comparative histological study of wound healing following $\mathrm{CO}_{2}$ laser and conventional surgical excision of canine buccal mucosa. Archs Oral Biol 28: 287-291 1983.

16) 大久保 泰: 顕微鏡下喉頭内レーザー手術に関 する基礎的研究. 耳鼻 26：29-43 1980 .

17) Shaw, J.H., Sweeney, E.D., et al.: Textbook of oral biology. W.B. Saunders, Philadelphia, 1978, p 937-954.

18) Engler, W., Ramfjord, S., et al.: Healing following simple gingivectomy. A tritiated thymidine radioautographic study. I. Epithelization. J Periodont 37: 298-308 1966. 